Cracow Indological Studies

Vol. XXI, No. 2 (2019), pp. 159-178

https://doi.org/10.12797/CIS.21.2019.02.06

\author{
David Pierdominici Leão \\ david.pierdominici@gmail.com \\ (IIAS, Leiden, Netherlands)
}

\title{
Through the Eyes of a Warrior, Traveller and Poet: Portugal, Malabar and Indian Traditions as Seen by Luís Vaz de Camões (Os Lusíadas VII, 17-85)
}

SUMMARY: An adventurer, soldier and great poet, Luís Vaz de Camões (15241580) arrived in India in 1555 and remained there till 1567, with ups and mishaps. The author of the Portuguese national epic poem, Camões recounted in a marvellous poetic form the heroic crossing of Vasco da Gama, who reached the Calicut coasts in 1498, skirting for the very first time the Cabo da Boa Esperança (Cape of Good Hope). The paper focuses on the analysis of some ottavas from the $7^{\text {th }}$ canto of Os Lusiadas, in which the arrival of Portuguese sailors and the first meeting with emissaries from the Zamorin are narrated. These passages, concerning the religious and cultural traditions of Malabar (but Indian in general) and its political organization, will be the starting point for a reflection on Indo-Portuguese relationships, as seen not from a historical source, but from a little-studied literary one.

KEYWORDS: Camões, Portuguese literature, colonial history, Indo-Portuguese relations, Kerala

Luís Vaz de Camões, the prince among Portuguese authors, is acknowledged to be one of the greatest literary voices in late Renaissance European literature. For his mastery of verse and poetical imagination he is frequently and traditionally compared to literary giants such as Homer, Vergil, Dante Alighieri, Shakespeare, Torquato Tasso and van den Vondel. The centuries have preserved several accounts of his life, often 
mixed with fabulous and unrealistic details. Despite the great amount of information about Camões's biographical vicissitude, his figure is shrouded in a sort of mystery, clouded in fact by a legendary aura and anecdotal tales carried by biographers over the ages. ${ }^{1}$ To begin with, for instance, there is no certainty about the birth date of the Portuguese poeta laureatus: according to different sources, the dating swings between 1524 and 1526. Even his birthplace is not sure; some biographies place it in Lisbon, other in Alenquer and Santarém, the centres of the paternal and maternal branches of his family. ${ }^{2}$ Nothing certain is known about Camões's childhood. It seems probable that all of the poet's education took place in Coimbra at the Faculty of Arts and Humanities of the university, which constituted the major centre of Portuguese culture and one of the most influential formative academies during the humanistic era.

His aristocratic birth facilitated the access of the young talented poet into the courtly life of the capital when the country was ruled by King Dom João III (1502-1557). Nevertheless, his choleric nature and intemperance started to damage his position and the favour Camões found in the ruler. The poet's crusty behaviour and many illicit loves forced him to abandon Lisbon and take refuge in the neighbouring areas. Shortly after, probably in 1547, Camões embarked on a military campaign in Africa. Legend has it that the poet lost an eye during a battle in Ceuta. ${ }^{3}$ In 1548 he finally returned to Lisbon, where he lived in desperate economic conditions. There, because of a fight with a hostler during a religious festival, Camões decided to leave for India in order to avoid capture and imprisonment. The poet reached

1 For the following schematic account of Camões's life - thematics beyond the scope of the present paper-I make reference to Saraiva 1978.

Alenquer is nowadays a Portuguese municipality in the Estremadura district; Santarém is the principal centre of the ancient Ribatejo area.

Camões is traditionally portrayed without the right eye in a series of unofficial and mythical illustrations; despite the legend, the author's presence in Ceuta is remembered in the elegy Aquela que de amor descomedido (Cidade 1973: 410-412), dedicated to Antão de Noronha. 
India in 1554, where he took part in several military actions in which he distinguished himself. Due to received honours, the new governor of Portuguese India, Dom Francisco Barreto (1555-1558), ${ }^{4}$ decided to send Camões to Macao, a diplomatic appointment, from which he would be soon removed. The years 1554-1561 were a time of tragic wanderings and misfortune. Returning to Goa from China, he was shipwrecked and lost all his possessions, except for the manuscript of his immortal poem, Os Lusiadas. In the following decade (1561-1567) Camões was again in Goa, ruled then by Dom Francisco Coutinho. Due to debts contracted in Macao, the poet was arrested and imprisoned. During his isolation, he dedicated his efforts to the composition of his masterpiece. In 1567 he embarked on a journey to Portugal. After a new, but brief detention in Mozambique, and after seventeen years of absence, Camões reached the capital, having already completed his poem. But the poet was by now completely forgotten. He will spend the rest of his life in general indifference and will die in 1580, probably of plague. Despite the exquisite character of his several poetical compositions, Camões's literary glory is embodied by his magnum opus, $O s$ Lusiadas, "The Lusiads". ${ }^{5}$ This is an epic poem in ten cantos composed in Homeric fashion, focused on a fantastical interpretation of Portuguese voyages of discoveries at the end of the $15^{\text {th }}$ century. The main nucleus is preceded by a lengthy description of Portuguese history, from the reign of Dom Afonso Enrique (1109-1185) to the Spanish conquest and the formation of the Iberian union under the Habsburg monarchy (1580). Os Lusiadas is dedicated to King Dom Sebastião I (1554-1578), the last monarch of the Avíz

4 The poet, while in India, celebrated the appointment of the $18^{\text {th }}$ governor with the composition of one of his most notable works, the Auto de Filodemo.

5 The poem was published in Lisbon in 1572, with the caption "Os/ Lusiadas/ de Luis de Ca/mões/ Com privilegio /Real/ Impressos em Lisboa, com licença da/ Sancta Inquisição, \& do Ordina/ rio: em casa de Antonio/ Gõçalves / Impressor/ 1572”. For studies and general appreciation on the epic poem see Hart 1962 and Monteiro 2010: 119-132. 
dynasty (1385-1580). ${ }^{6}$ The centre of the epic poem is devoted to the narration of the journey of Vasco da Gama (1448-1524), the Earl of Vidigueira and Admiral of the Indian Ocean, who, after having skirted the Cape of Good Hope in 1497, reached Kozhikode (Calicut) in 1498 and settled the first Portuguese trading post on the Indian subcontinent. ${ }^{7}$ The $7^{\text {th }}$ canto of Os Lusiadas opens with the arrival and the entrance of Portuguese ships into Calicut harbour. Starting from ottava 17, Camões interrupts his narration in order to offer a general description of India, with an accentuated humanistic flavour. Quoted below is the related stanza: ${ }^{8}$

Além do Indo jaz e aquém do Gange

Um terreno mui grande e assaz famoso

Que pela parte Austral o mar abrange

E pera o Norte o Emódio cavernoso.

Jugo de Reis diversos o constrange

A várias leis: alguns o vicioso

Mahoma, alguns os Ídolos adoram,

Alguns os animais que entre eles moram. || L. VII, 17 ||

Beyond the Indus river and on this side of the Ganges there is a very big and famous land, lapped by the sea in the South and in the North by the deep Himālaya. The yoke of many different kings leads to many beliefs: some worship the vicious Muhammad, some idols, while others animals which live among them.

6 The young king died at the age of 24 in the disastrous battle of Alcazarquivir (Morocco) in 1578, while Portugal was fighting against al-Maghrib al-Aqșā Sultan Abū Marwān 'Abd al-Malik I al-Sa 'dī (1576-1578). For a reference to this fundamental moment of Portuguese history please consult Livermore 1976: 151-158.

7 A detailed account of the voyages of Vasco da Gama is unfortunately impossible on these pages; among the generous bibliography, the interested reader may find it useful to consult Ames 2008 and Subrahmanyam 1997. For direct contact with primary sources refer for instance to Ravenstein 1898.

8 For the text of Os Lusiadas I make reference to the edition in Cidade 2007; I have made occasional use of a digital copy of the 1572 editio princeps. All the translations in the present article are by the author. 
This geographical depiction of the sub-continent, the borders of which are marked respectively by the presence of the Himalayan mountains in the north and by the ocean in the south, evidences the traditional topographical influence of western geography, which was highly developed thanks to Portuguese discoveries of that time (Burton 1881: 462). Emódio is indeed the Ptolemaic name used to denote the Himālaya, from that classical tradition which Camões certainly absorbed during his education at Coimbra University. ${ }^{9}$ Following the same traditional western trend, the poet gives in ottava 19 a primary "anthropological" consideration related to the Indian population:

.... junto donde nasce o largo braço

Gangético, o rumor antigo conta

Que os vizinhos, da terra moradores,

Do cheiro se mantêm das finas flores. || L. VII, 19 ||

$[\ldots]$ and just where the Gangetic stream is born, ancient legend has it that the inhabitants feed on the fragrance of marvellous flowers.

This fabulous statement is sustained by a clue which comes from ancient classical and Roman ethnography. The image of people from India feeding on flowers is drawn from the historian Pliny the Elder, who, quoting Ancient Greek author Megasthenes, described a particular Indian tribe. Below is a section from the seventh chapter of his Naturalis Historia:

ad extremos fines Indiae ab oriente circa fontem Gangis Astomorum gentem sine ore, corpore toto hirtam vestiri frondium lanugine, halitu tantum viventem et odore, quem naribus trahant. nullum illis cibum nullumque potum, radicum tantum florumque varios odores et silvestrium malorum, quae secum portant longiore itinere, ne desit olfactus... || NH, VII, 25 ||

9 The term Emódio (Latin [H]emodus) was employed in the Historia Naturalis by Pliny the Elder (VI, 17, 21; Mayhoff 1906: 453) and referred to the mountain range of Ancient Persia. 
At the extremity of India, from the east, and close to the sources of the Ganges, [there is] the tribe of the Astomi ${ }^{10}$, who do not have mouths, their hairy body covered by tree leaves. [These people] subsist only on the air and the fragrance, which they inhale through the nostrils. They support themselves upon neither food nor drink, but only on various smells of roots, flowers and berries, which they carry during a long journey, in order that they do not lack something to smell $[\ldots]$.

After this legendary description, Camões reports the names of different Indian populations, who "de nomes e de usança/ novos e vários são" ("are very different for names and customs") and who are described again according to the usual classifications of the classical geography. The poet lists the Deliis, Patanes and Oriás, who were traditionally and respectively inhabitants of Northern India and the Gangetic Valley. Finally, there is mention of the Decanis, who, as the word obviously suggests, were residents of the Deccan plateau (ottava 20).

In the following stanza, after a brief and somehow unrealistic description of Indian ethnography, Camões drew a brief political scenario of the sub-continent, always using the same descriptive polarity between North and South which we have already perceived in the geographical section. The relative passage follows below:

O Reino de Cambaia belicoso

(Dizem que foi de Poro, Rei potente);

O Reino de Narsinga, poderoso

Mais de ouro e pedras que de forte gente.

Aqui se enxerga, lá do mar undoso,

Um monte alto, que corre longamente,

Servindo ao Malabar de forte muro,

Com que do Canará vive seguro. || L. VII, 21 ||

10 The word Astomi is derived from Ancient Greek and means "without a mouth/teeth". Apart from the mythological account reported by Pliny, perhaps the detail of having no mouth can hypothetically be interpreted in a different way, namely denoting a different kind of language and the impossibility of mutual communication. 
The warlike kingdom of Cambaia (it is said to have belonged to the powerful King Porus); the reign of Narsinga, richer in gold and gems than in brave people. Beyond the wavy sea, one can see a big mountain, which lies in a large space, protecting the Malabar area and guarding it from Karnataka.

Porus, as is known, is the Latinization of the Greek name of the Paurava King who ruled in the $4^{\text {th }}$ century BCE and who strenuously fought against the invasion of Alexander the Great, as narrated by historians Arrian (V, 29,2) and Curtius Rufus (VIII, 14), and referred to by polymath Plutarch (60) as well. Narsinga is the Portuguese form for the Sanskrit Narasimha, a term which denoted the great empire of Vijayanagara (1336-1565), still surviving, even if in a weak condition, in Camões's time. ${ }^{11}$ After these introductory stanzas, and following the description of Vasco da Gama's entrance into Kerala, the author gave a brief account of the locality the Portuguese had just reached, Calicut: ${ }^{12}$

[...] Aqui de outras cidades, sem debate, Calecu tem a ilustre dignidade De cabeça de Império, rica e bela;

Samorim se intitula o senhor dela. || L. VII, 22 ||

[...] here, among other cities, beyond any doubts, Calicut has absolute dignity, the first of the Kingdom, rich and wonderful; Zamorin is the Lord who rules over it.

11 The denomination of Narsinga (probably after the most famous and symbolical monument in Hampi, god Narasimha's monolithic statue) was already previously used, together with "Bisnaga", by two Portuguese traders and travellers, who visited Vijayanagara during the $16^{\text {th }}$ century, Domingo Pães and Fernão Nunes; consult Sewell 2012. If we consider the political situation of the South Indian Empire as contemporary to Vasco da Gama, the kingdom was then ruled by Immadi Narasiṃha (1491-1505). If contemporary to Camões, we must assume the rule by Aḹya Rāmarāya (1542-1565), Kṛ̣ṇadevarāya's son-in-law and regent of the "puppetemperor" Sadāśiva (1542-1576), or by Tirumaladevarāya (1565-1572), the exiled king in Penukondia, after the havoc of Vijayanagara in 1565. For further details see Nilakanta Sastri 1958: 266; 278-286.

12 In reality, the Portuguese fleet did not land in Kozhikode, but in Kappad, a locality situated $18 \mathrm{~km}$ away from it. 
Calecù is the ancient Portuguese form of the name Kozhikode, the most important and strategical point of the Malabar coast for trading purposes. ${ }^{13}$ Zamorin is the Western variant of the title (biruda) used by the post-Cera Eradịi rulers, namely Samutiri Manavikramarāja, who ruled over the area from the $12^{\text {th }}$ to the $18^{\text {th }}$ century. The powerful dynasty ruled over an independent area till 1766, when Mysorean Haider Ali defeated the Zamorin and absorbed the territory into his state. After the Third Mysore War (1790-1792), the Zamorins will be under the direct control of the East India Company till $1806 .{ }^{14}$

Starting from ottava 24, Camões introduced a turning point in the plot of his epic poem. In Calicut harbor, Portuguese sailors met with an obscure character, a certain Monçaide, an Arabian citizen of Kerala who is able to speak Portuguese and to communicate with Vasco da Gama and his men. After brief introductory speeches, Monçaide, now the guide of the adventurers, started to illustrate the mythical origins of Kerala and Calicut (ottavas 30-36). ${ }^{15}$ Through his voice,

13 The name of Kozhikode is of uncertain origin. The Portuguese (and English) form of the toponym, Calicut, seems to derive from the Arabic Qāliqūt (as called for instance by Abū 'Abd al-Lāh Muḥammad Ibn Batțūṭa, the Moroccan $14^{\text {th }}$ century traveller. Please consult Gibb 1994: 812).

14 For a comprehensive history of the Zamorins of Calicut consult Krishna Ayyar 1938, especially 138-220 for the complex relations between the local rulers and the Portuguese, and Raja 1966.

15 Camões, following an unspecified source, gave a curious account about the origin of Calicut and the Zamorin Kingdom (VII, 32-36). According to legend, in ancient times the whole Keralan area was ruled by an only monarch, Seramá Perimál; once, meeting at the harbour with some Arabian traders, he converted to Islam and decided to follow a pilgrimage to Mecca, where he would die. Before leaving, the sovereign would have divided his kingdom into small principalities, entrusted to the people; from one of these divisions, Calicut reign was born. Despite the probable character of unreliability of this account, it is noteworthy to observe how some contemporary Muslim sources speak in the same term. Zain al-Din, historian of the $16^{\text {th }}$ century, in his work Tuhfat al Mujahii, defined the Zamorin as "a friend for the Muslims", due to his patronage to the trading community of the Mappillas, one of the most consistent Muslim groups in Kerala still nowadays. The same scholar drew the origin of the community, asserting that a Malabar king, in $822 \mathrm{CE}$, converted to the Islamic 
the poet, after the geographical and ethnographical accounts, illustrated the "sociological" divisions of Malabar, or in general Indian, society. Below is the relative passage:

A Lei da gente toda, rica e pobre,

De fábulas composta se imagina.

Andam nus e somente um pano cobre

As partes que a cobrir Natura ensina.

Dous modos há de gente, porque a nobre

Naires chamados são, e a menos dina

Poleás tem por nome, a quem obriga

A Lei não mesturar a casta antiga. || L. VII, 37 ||

The faith of all people, either rich or poor, is characterised by several fabulous tales. They go completely naked and only a rag covers their genitals. Among the people there are two ways of being: the noble ones, called Naires, and the miserable ones, Poleas, who are obliged by the Law to not mix with that ancient caste [the former].

Camões, in his description, divided Malabar society into two main sociological groups, namely the Naires and the Poleas. Surprisingly, considering the previous legendary accounts, centred on the Classical and Humanistic formative background, in this ottava the Portuguese poet showed a correct interpretation of the Indian division of the Malabar community. Even if the mention of Poleas is almost immediateand an evident Portuguese corruption for Pariah, "outsider"- the one of Naires needs some elucidations.

The Nairs (or Nayars, according to another way of spelling) ${ }^{16}$ maintain a well-attested presence through the centuries in the whole

faith and left for Arabia. After his death, his fame started to spread and he became famous under the appellative of Al' Samuri ("The Sailor"), then corrupted in Zamorin. Even if it appears obvious that the existence of these legends were due to the protection accorded by the Hindū local rulers to the Islamic communities of Kerala, the parallel between Camões's description and the Muslim sources is curious and symptomatic.

16 The first occurrence of the term can be traced again in Pliny the Elder, Naturalis Historia VI, 20, 23, "Nareae" (Mayhoff 1906: 461). 
Malabar area. European scholars erroneously identified them as members of the ksatriya caste, due to the accentuated military connotation of this group. More properly, the Nayars are a group of India castes attentively studied by Kathleen Gough and Cristopher Fuller (Gough 1961; Fuller 1975). Examining the many subdivisions pertinent to this community, Gough observed that they are "not a unitary group but a named category of castes" (Gough 1961: 312). Historically, Nayar identity is organised around the tharavad ${ }^{17}$ system, based upon several family units, related to the preponderant matrilineal organisation in Kerala, marumakkathayam. The importance of this Dravidic community was also connected to the elaborate marriage rituals - no longer performed nowadays - as the pre-pubertal thalikettu kalyanam or the sambandham, which allowed polygamy for men and, through the connection with the Nambudiri Brahmins, hypergamy for women (Fuller 1975: 296-302).

From an excerpt of stanza 38, the poet described the relation between the two groups, spotting one of the founding pilasters of the Hindu dharma, namely the contrastive polarity between purity and impurity, śuddhi and aśuddhi: ${ }^{18}$
[...] Pera os Naires é, certo, grande vício
Destes serem tocados; de tal sorte
Que, quando algum se toca porventura,
Com cerimónias mil se alimpa e apura. || L. VII, 38 ||
[...] verily, for the Naires is a great sin to be touched by them; if this happens by chance, they purify themselves with several ceremonies.

In referring to this traditional prescription, Camões, for the very first time in the descriptive section, showed a habit which will be examined

17 According to Gundert (Gundert 1872: 434), the term is listed with the meaning of "ancestral residence of land-owners" and, also, as "a house, chiefly of noblemen".

18 Monier-Williams (Monier-Williams 2005: 1082; 113) gives respectively the meaning of "cleansing, purification, purity" and "impurity". 
even later and will be of the foremost importance for the aim of the present article. We should not forget that the Portuguese poet was a fervent Catholic, but, surprisingly, it cannot be stated that he judged or scorned the matter he was treating. The descriptive passages show beyond doubt a willingness to observe and understand Indian customs and tradition; in doing this, the author tried to analyse them resorting to his religious and cultural background. The alternation between purity and impurity in the Indian world is understood comparing it to the Judaic and Christian tradition, where "in the same way, the ancient Jews did not have contact with the Samarian people" ("desta sorte o judaico povo antigo/não tocava na gente de Samária...", ottava 39).

Monçaide went on with his description of Malabar society and India, a marvellous land in which the Portuguese sailors will find "strange/odd things" (wonders?). ${ }^{19}$

The last depiction is devoted to the religious customs of the Indian population; Camões did not directly observe rituals or ceremonies, but depicted a general outline of the performers and repositories of the religious practice, namely the Brahmins:

Brâmenes são os seus religiosos,

Nome antigo e de grande preminência;

Observam os preceitos tão famosos

Dum que primeiro pôs nome à ciência;

Não matam cousa viva e, temerosos,

Das carnes têm grandíssima abstinência.

Sòmente no Venéreo ajuntamento

Têm mais licença e menos regimento. || L. VII, 40 ||

19 In stanza 39 we find the term "estranhezas", which possesses highly pregnant in meaning, and referring to the marvellous character of India. Being far from a negative connotation, we will find the adjective "estranho", "strange, unfamiliar" referred to Vasco da Gama in ottava 49, in which Camões described the journey of the Portuguese travellers to the Zamorin Palace. The local people will observe the white "strange" men with curiosity and wonder. The play upon the meaning of the term seems to convey the character of the relation between the Portuguese and the Hindū populations, which must have appeared unfamiliar to each other. 
Brahmins are their religious men, an ancient and pre-eminent name; they observe the renowned precepts of the first who created the science. They do not kill any living being and, respectfully, eschew meat; only in the sexual intercourse do they show debauchery.

It would be extremely suggestive if Camões referred directly to Indian terminology and names in these lines: the hint to "the first who created the science" could be referred to Brahmā or Bṛhaspati, the Sage who, according to the Rgveda, was born from the first light, who can drive away darkness and is traditionally considered as the guru of all Devas and the chief performer of all sacrifices. "20 "Science" appears evocative of śastra; the last depreciative observation probably refers to the custom of polygamy among Hindū Brahmins, while the claim of non-violence is a clear and direct reference to the ahims ā principle.

In the second part of the seventh canto Vasco da Gama and his officials met with the Catual, the emissary from the Zamorin surrounded by a group of armed Nayars, who invited the sailors to the Palace of the ruler (ottavas 42-44). In their journey through Calicut, while conversing with the Catual, the Portuguese stopped in front of a temple and examined the decoration:

Ali estão das Deidades as figuras, Esculpidas em pau e em pedra fria,

Vários de gestos, vários de pinturas, A segundo o Demónio lhe fingia;

Vêm-se as abomináveis esculturas,

Qual a Quimera em membros se varia;

Os cristãos olhos, a ver Deus usados

Em forma humana, estão maravilhados. || L. VII, 47 ||

20 Rgveda IV, 50 (stanza 4):

brhaspatih prathamam jāyamāno maho jyotișah parame vyoman |

saptāsyastuvijāto ravena vi saptaraśbhiradyamattamāmsi $\|$ 
There were images of deities engraved in wood and stone, manifold for gestures, different in their depiction, as the Devil/demon represented them [lit. "pretended them"]. Terrific sculptures were seen, as polymorphic Chimeras; the Christian eyes, used to seeing God in human form, are astonished/amazed.

This wonderful ottava-probably one of the most beautiful of the whole Os Lusiadas - depicts all the marvel and astonishment of the Portuguese voyagers in front of some temple decorations and representations of Hindū divinities. Recently, Michael Murrin (Murrin 2003) has briefly analysed this stanza, inserted in a wider perspective about the first encounters and mutual perception between the Portuguese and Indian local population at a religious level. Basing his observations on the objectivity of the first reports and journey relationsas the diaries by Vasco da Gama-Murrin claimed:

[...] The Portuguese in their encounter with Hindus at Calicut or Kozhikode did not wonder because they made almost a complete religious identification of themselves with the Hindus. They never realized that Hindus were not Christians, nor during their visit of some months was the illusion ever dispelled. On their return to Lisbon the leaders of the expedition still identified Hindus as Christians [...]. (Murrin 2003: 190)

Even before the first naval voyage of discovery, the Portuguese were aware of the existence and presence of Christians in India. This is confirmed by the several descriptions and accounts left by the traveller preceding Vasco da Gama, Pero de Covilhã, who, historically, is considered the first Portuguese figure to have reached Goa by ship and on foot. Analysing the primary original sources of the first encounter and visit of da Gama to the Zamorin, Murrin evidenced how the chroniclers extensively referred to the depictions and carvings on Hindū temples in Kerala as well as the way of worshipping and concluded how "the Portuguese did not object to the images as images but to the kinds of images they saw in the Hindu temple..." and, as a consequence in the Portuguese view, that "the Hindus were defective Christians" 
(Murrin 2003: 195-196). In order to explicate and support his view, the scholar made use of the last examined stanza from Os Lusiadas. Trying to motivating this climate of mutual religious and identity misunderstanding, Murrin observed:

The poet Camões, who made an epic out of Da Gama's voyage, [...] elaborated on this scene and provided a rationale for his reaction. In the epic the Portuguese see instead of paintings statues in wood or stone, some with repugnant shape. The statues seem wondrous to the Portuguese [...] Camões, of course, was better informed than the author of the Roteiro yet the rationale he gives for the rejection turns on the same thing which troubled the earlier visitor. Hindus do not always preserve the human form in their statues, while the Portuguese in contrast are used to seeing God only in human form. The poet thus tacitly evokes both Genesis 1:27, the priestly claim that human beings were made in the image of God. God became man to save humankind. Statues like Ganesha with a human body and the head of an elephant would make no sense to a Christian. (Murrin 2003: 195)

In my opinion, I do think that Murrin's conclusion is not coherent to the poetic text of Os Lusiadas. Even if the analysis of the previous primary sources may evidence a condition of a Portuguese-Hindu religious misunderstanding, using a later-and poetical-document as a confirmation of these statements is not convincingly pertinent. The reason is obviously the most immediate: as we have previously seen during the biographical excursus, the poet spent almost seventeen years in India and we could easily imagine he gained a certain acquaintance with the cultural world surrounding him. Claiming a persistent mutual religious confusion in the poetical work of Camões is in an evident contrast with the analysed passages, in which, sometimes, the author shows a considerable knowledge of India and its traditions and its character of alterity. The ottava 47 depicts Portuguese travellers in front of the manifold representation of Hindū divinities, which are clearly perceived as alter-in the Latin sense of the term- "strange, 
odd, unfamiliar" and not as distorted abominations from Christian tradition. The astonishment of the foreign watchers in front of the "chimerical figures" ${ }^{21}$ is mirrored also at the poetic level, where the distorted syntax of the stanza seems to imitate the marvel, the curiosity and, why not, the fright of the foreigners' "Christian eyes" in front of a new and inexperienced world as is India of "remoda antiguidade" (“distant antiquity", ottava 51).

Moreover, this first real encounter between the PortugueseChristian and Hindū realities is immediately after (stanza 48) glossed by Camões according to the usual custom of comparing new traditions to already pre-existent ones in the poet's educational horizon. Below is ottava 48:

Um, na cabeça cornos esculpidos,

Qual Júpiter Amon em Líbia estava;

Outro, num corpo rostos tinha unidos,

Bem como o antigo Jano se pintava;

Outro, com muitos braços divididos,

A Briareu parece que imitava;

Outro, fronte canina tem de fora,

Qual Anúbis Menfitico se adora. || L. VII, 48 ||

One has horns on the head, as Zeus Ammon in Africa; another has several faces on one body, as the ancient Janus was represented. Another one with many arms seemed to imitate the giant Briareus; another appears with a canine head, as Anubis in Memphis was worshipped. ${ }^{22}$

21 The expressions "abomináveis esculturas" and "Quimera"-from the celebrated monster of Ancient Greek mythology — could have several explanations. First of all, it can be referred to the manifold and, as every scholar of Indology knows, various iconography of the Indian pantheon. The almost animalistic character of the representations in stanza 47 can also be interpreted as a reference to the nāgas or other theriomorphic minor divinities from classical Hindū or Dravidian traditions.

22 If we follow Murrin's interpretation, that in the Portuguese perception Indian identity and traditions were viewed as a simple aberrant distortion of Christianity, we would logically expect Camões to compare Hindū representations to some corresponding ones drawn out from the Catholic tradition (as, for instance, in the case of Saint 
The rest of the seventh canto (stanzas 49-77) will be devoted to the description of the official meeting of Vasco da Gama and the Portuguese sailors with the Zamorin court.

Having finished the study of ottavas concerning the description of India and its world, it would be beneficial to sum up and draw some conclusions. From the above analysis, it will appear evident how the attitude of Camões in observing the Indian reality can be divided according to two main dynamics. The first one derives from the academic and educational formation of the poet, centred on the influence from the Classical tradition and geography-ubiquitous during the Renaissance era. It would be enough to think about the deep presence of passages retrieved from the Roman authors and centred on the traditional Ptolemaic topography. But, it would not be improbable to presume a personal experience and direct observation by such a traveller as Camões of the Indian world.

Even being first of all a Christian man talking about "bárbaro gentio" ("barbarian people", ottava 49), the poet never shows disgust or harsh judgement against its poetical matter. In Os Lusíadas's pages it seems that the Portuguese are in front of something greater than them: they have truly discovered a new world and they are looking at it with surprise and curiosity, a curiosity which is undoubtedly shared by Camões. Before being a warrior and a poet, Camões was a real traveller: he observed, described (and he was quite correct in his depictions) and tried to understand, comparing what he had probably seen to what he knew, with a constant play of cross-references.

In my opinion, there is even something more. The last stanzas of the canto are dedicated to personal considerations by the poet, who interrupted the fictional narration of the historical matter to lament his tragic situation and his fate, as we would remember from the biographical excursus. Ottavas 81 and 85 are of the foremost interest:

Christophorus, depicted with a dog's head). Probably not without reason, the comparison is taken by the Christian poet from the Pagan world! 
E ainda, Ninfas minhas, não bastava

Que tamanhas misérias me cercassem,

Senão que aqueles que eu cantando andava

Tal prémio de meus versos me tornassem:... || L. VII, 81 ||

Nenhum que use de seu pode bastante

Pera servir a seu desejo feio,

E que, por comprazer ao vulgo errante,

Se muda em mais figuras que Proteio.

Nem, Camenas, também cuideis que cante

Quem, com hábito honesto e grave, veio,

Por contentar o Rei, no oficio novo,

A despir e roubar o pobre povo! || L. VII, 85 ||

Moreover, my Nymphs, it was not enough that so harsh miseries persecuted me, which those I celebrated threw me in because of my verses... (81).

Nobody who uses his power to satisfy dishonest desires, nobody who, pleasing fickle people, sloughs like manifold Protheus. Camenas! You do not want me to celebrate anybody who, with honest semblance, in new appointments, fleece and robe the people to satisfy the King! (85).

Portuguese scholars (as in Cidade 2007: 429, note for ottava 85, 5-6) tend to interpret the expression "anybody who, with honest semblance, in new appointments, fleece and robe the people to satisfy the King" with an indirect allusion to two powerful characters of the Portuguese history of that time, the Gonçalves da Câmara brothers, protégée of the King Dom Sebastião I. Particularly hostile to Camões, they were religious men, as the periphrasis "com hábito honesto e grave" seems to allude to here. Anyway, what would have been the purpose to attack these figures in a poetical portion devoted to India? Traditionally, Camões is acknowledged to be the author of a satirical piece, entitled "Disparates na Índia" ("Madness in India"; Cidade 1973: 86-91), dated to 1555, in which the poet denounced Portuguese violence towards and abuse of the Indian population of Goa, because of which he was exiled to Macao, officially under diplomatic appointments by 
the Governor Dom Francisco Barretto (de Carvalho Nunes: 2012). ${ }^{23}$ It seems probable that the same assertions in Os Lusiadas can be equated to the same accusations perpetrated by Camões in his satire. If this interpretation would be acceptable, we can observe a critique by a Portuguese poet against the Portuguese authorities of Goa; Camões then would not be only a Christian poet who described India and looked at it with an amazed and curious eye, but who also criticised his own people for its savagery against the local population.

The essence of "crossing boundaries" is abundantly present in the poet's verses and their elaboration; Camões's travels were not only a crossing of physical boundaries, but they were an attempt to understand a different culture. He was a foreigner who tried to overstep or use his own background to meet with and discover "again" a new world, which constitutes the essence of every journey.

The world and the experience which Camões and the Portuguese have found, its beauty and "estranhezas" is beautifully synthesised by the wonderful words of Vasco da Gama to his crew at seeing the Keralan coast:

Esta é por certo a terra que buscais

Da verdadeira Índia, que aparece;

$E$, se do mundo mais não desejas, Vosso trabalho longo aqui fenece. || L. VI, 93 ||

This is certainly the land you were looking for, the authentic India, which you now see; and if you do not desire anything more from the world, here all your long fatigues reach the end.

23 This seems highly probable, considering the dating of the work and the rule of the Governor, the same Governor celebrated by Camões with the Auto de Filodemo. See note 4. 


\section{References}

\section{Primary sources}

Cidade, H. (ed.) 1973. Luís de Camões: Lírica. Rio de Mouro: Círculo de Leitores.

—. 2007. Luís de Camões: Os Lusíadas. Rio de Mouro: Círculo de Leitores.

Camões, L., de 1572. Os Lusíadas (Os/ Lusiadas/ de Luis de Ca/ mões/ Com privilegio/ Real/ Impressos em Lisboa, com licença da/ Sancta Inquisição, \& do Ordina/rio: em casa de Antonio/Gõçalves/Impressor/ 1572). Retrieved from: https://archive.org/details/oslusiadasdeluis00cam [18.10.2019].

Gibb, H. A. R. (transl.). 1994. The Travels of Ibn Battuta A.D 1325-1354, Vol. IV. London: The Hakluyt Society.

Mayhoff, K. F. T. and L. von Jan (eds). 1906. C. Plini Secundi Naturalis Historia Libri XXXVII. Leipzig: Teubner.

Ravenstein, E. G. (ed. and transl.). 1898. A Journal of the First Voyage of Vasco da Gama, 1497-1499. London: The Hakluyt Society.

Rgveda, with the Commentary of Sāyaṇāchārya, vol. II (2-5 Maṇdalas). 1936. Poona: Vaidika Samshodhana Mañdala. 1936.

Travillian, T. T. (ed.). 2015. Pliny the Elder. The Natural History Book VII (with Book VIII 1-34). London: Bloomsbury Latin Texts.

Zain Al Din. Tuhfat al Mujahii. Deccan, Hyderabad. s.d.

\section{Secondary sources}

Ames, G. J. 2008. The Globe Encompassed: The Age of European Discovery (1500 to 1700). New York: Pearson.

Burton, R. B. 1881. Camoens: His Life and His Lusiads. London: Bernard Quartich.

De Carvalho Nunes, V. 2012. "Disparates" ou o bom senso de Camões?. In: S. Pereira and M. Ferro (eds). Actas da VI Reunião Internacional de Camonistas. Coimbra: Universidade de Coimbra: 281-287.

Fuller, C. J. 1975. The Internal Structure of the Nayar Caste. In: Journal of Anthropological Research, 31(4): 283-312. https://doi.org/10.1086/ jar.31.4.3629883. 
Gough, K. 1961. Nayar: Central Kerala. In: D. M. Schneider and K. Gough (eds). Matrilineal Kinship. Berkeley-Los Angeles: University of California Press: 298-385.

Hart, H. H. 1962. Luis de Camoens and the Epic of the Lusiads. Norman: University of Oklahoma Press.

Krishna Ayyar, K. V. 1938. Zamorins of Calicut: from the Earliest Times to $A D$ 1806. Calicut: Norman Printing Bureau.

Livermore, H. V. 1976. A New History of Portugal. Cambridge: Cambridge University Press.

Monteiro, G. 2010. Camões's Os Lusíadas: The First Modern Epic. In: C. Bates (ed.). The Cambridge Companion to Epic. Cambridge: Cambridge University Press: 119-132.

Murrin, M. 2003. First Encounter: The Christian-Hindu Confusion when the Portuguese Reached India. In: s.n. Post-Imperial Camões. Center for Portuguese Studies and Culture: University of Massachusetts Dartmouth: 189-202. https://www.doi.org/10.7208/chicago/9780226071602.003.0007.

Nilakanta Sastri, K. A. 1958. A History of South India: from Prehistoric Times to the Fall of Vijayanagar. Madras: Oxford University Press.

Raja, P. K. S. 1966. Medieval Kerala. Calicut: Navakerala Co-op Publishing House.

Saraiva, J. H. 1978. Vida Ignorada de Camões: uma história que o tempo censurou. Rio de Mouro: Mem Martins Publicações Europa-America.

Subrahmanyam, S. 1997. The Career and Legend of Vasco da Gama. Cambridge: Cambridge University Press.

\section{Dictionaries}

Gundert, H. 1872. A Malayalam and English Dictionary. Mangalore: Basel Mission Books.

Monier-Williams, M. 2005. A Sanskrit English Dictionary. Etymologically and Philologically Arranged with Special Reference to Cognate IndoEuropean Languages. New Delhi: Asian Educational Services. 